\title{
Meningkatkan Profesional profesi Guru Menuju Indonesia Cerdas
}

\author{
Bachtiar \\ Email: 2010111110003@mhs.ulm.ac.id \\ Program Studi Pendidikan Sejarah Fakultas Keguruan dan Ilmu Pendidikan \\ Universitas Lambung Mangkurat \\ Banjarmasin
}

\begin{abstract}
Abstrak
Konsep Profesi adalah suatu jens pekerjaan yang menuntut kompetensi khusus melalui proses pendidikan yang lama pada pendidikan tinggi serta mendapat pengakuan dari masyarakat dan imbalan yang dapat mencukupi kehidupannya secara wajar. Berdasarkan UU RI No.14 tahun 2005 tentang guru dan dosen Pasal 1, guru adalah pendidik profesional dengan tugas utama mendidik, mengajar, membimbing, mengarahkan, melatih, menilai, dan mengevaluasi peserta didik Guru dapat diklasifikasikan sebagai profesi karena suatu jabatan yang memerlukan keahlian khusus sebagai guru dan tidak dapat dilakukan oleh sembarangan orang diluar pendidikan.Peran, Hak, dan kewajiban guru menurut Undang-undang No.14 tahun 2005 Profesionalisme guru diperlukan untuk memajukan pendidikan indonesia karena Dengan mengingat berat dan kompleksnya membangun pendidikan,Kompetensi yang harus dimiliki guru untuk dapat disebut sebagai guru profesional yakni kompetensi Profesional Guru, Pedagodik Guru, Sosial Guru serta Kepribadian Guru

\section{PENDAHULUAN}

Konsep Profesi adalah suatu jens pekerjaan yang menuntut kompetensi khusus melalui proses pendidikan yang lama pada pendidikan tinggi serta mendapat pengakuan dari masyarakat dan imbalan yang dapat mencukupi kehidupannya secara wajar. Jenis pekerjaan seperti yang digambarkan di atas salah satunya adalah jabatan guru. Guru merupakan jabatan profesi yang memiliki syarat khusus secara formal ( Nurzaman, Dkk,2019: 3 )
\end{abstract}


Profesi Guru, Berdasarkan UU RI No.14 tahun 2005 tentang guru dan dosen Pasal 1, guru adalah pendidik profesional dengan tugas utama mendidik, mengajar, membimbing, mengarahkan, melatih, menilai, dan mengevaluasi peserta didik pada pendidikan anak usia dini jalur pendidikan formal, pendidikan dasar, dan pendidikan menengah. (Susanto,2020: 16)

\section{PERAN GURU SEBAGAI SEBUAH PROFESI}

Guru dapat diklasifikasikan sebagai profesi karena suatu jabatan yang memerlukan keahlian khusus sebagai guru dan tidak dapat dilakukan oleh sembarangan orang diluar pendidikan. Walaupun pada kenyataannya masih terdapat guru yang tidak memiliki latar belakang pendidikan bidang keguruan. ( Susanto, $2020: 17$ )

Peran, Hak, dan kewajiban guru menurut Undang-undang No.14 tahun 2005 serta menurut para ahli. Menurut Djamarah (2000: 42-49) semua peran diharapkan dari guru seperrti diuraikan di bawah ini

a. Korektor

Peran ini mengaruskan guru memahami betul permasalahan dalam proses pendidikan. Sebagai korektor, guru harus bisa membedakan mana nilai yang baik dan mana nilai yang buruk.

b. Inspirator

Sebagai inspirator, guru dapat memberikan ilham yang baik bagi kemajuan belajar pserta didik. Dalam peran ini guru di haruskan untuk menjadi role model bagi peserta didik.

c. Informan

Sebagai informan, guru harus dapat memberikan informasi perkembangan ilmu pengetahuan dan teknologi, selain sejumlah bahan pelajaran untuk setiap mata pelajaran yang telah diprogramkan dalam kurikulum. 
d. Organisator

Sebagai organisator, dalam bidang guru memiliki kegiatan pengelolaan kegiatan akademik, menyusun tata tertib kelas/sekolah, menyusun rencana pembelajaran sesuai kalender akademik, dan sebagainya.

e. Motivator

Sebagai motivator, guru hendaknya mampu mendorong peserta didik agar bergairah dan aktif belajar.

f. Insiator

Sebagai insiator, guru harus dapat menjadi pencetus ide-ide kemajuan dalam pendidikan dan pengajaran. Insiator dimaksud mencakup peran insiatif guru dalam pembelajaran dan peran inisiatif guru dalam mengembangkan iklim belajarf di sekolah.

g. Fasilitator

Sebagai fasilitator, guru diharuskan untuk dapat memfasilitasi perserta didik dalam proses belajar mengajar

h. Pembimbing

Peran ini harus lebih dipentingkan, karena kehadiran guru di sekolah adalah untuk membimbing peserta didik menjadi manusia dewasa susila yang cakap.

i. Demonstrator

Dalam interaksi edukatif, tidak semua bahan pelajaran dapat peserta didik pahami. Untuk bahan pelajaran yang sukar dipahami peserta didik, guru harus kreatif untuk menunjukan langsung kepada peserta didik kemampuan yang dipelajari.

j. Pengelola kelas 
Tujuan umum dari pengelolaan kelas, yaitu menyediakan dan menggunakan fasilitas kelas bagi berbagai macam-macam kegiatan belajar mengajar agar tercapai hasil yang baik dan optimal.

k. Mediator

Sebagai mediator, guru harus memahami bagaimana siswa berinteraksi dan merespon suatu keadaan.

\section{Supervisor}

Dalam melakukan supervisi pembelajaran, guru harus menunjukan kemampuan untuk menawarkan alternatif solusi atas permasalahn yang ditemukan

m. Evaluator

Sebagai evaluator, guru setidaknya dihadapkan pada dua proses pemting, pertama proses mengukur keberhasilanbelajar peserta didik, kedua guru memberikan judgement ( nilai) yang akan menjadi tolak ukur apakah perserta didik berhasil dalam proses belajar atau belum berhasil

Dalam UU. No 14 Tahun 2005 tentang guru dan dosen pada bagian kedua mengenai hak dan kewajiban pada pasal 14, adapun hak yang di miliki eorang guru sebagai berikut :

a. Memperoleh pengahsilan di atas kebutuhan hidup minimum dan jaminan kesejahteraan sosial.

b. Mendapatkan promosi dan penghargaan sesuai dengan tugas dan presentasi kerja.

c. Memperoleh perlindungan dalam melaksanakan tugas dan hak atas kekayaan intelektual.

d. Memperoleh kesempatan umtuk meningkatkan kompetensi.

e. Memperoleh dan memanfaatkan sarana dan prasarana pembelajaran untuk menunjang kelancaran tugas keprofesionalan.

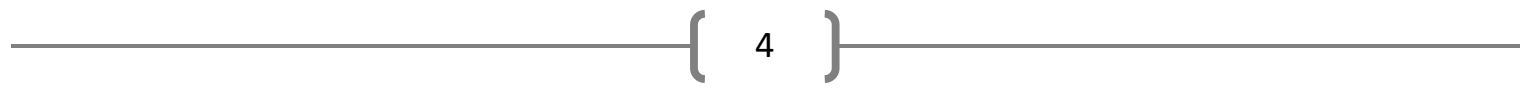


f. Memiliki kebebasan dalam memberikan penilaian dan ikut menentukan kelulusan, penghargaan, dan atau sanksi kepada peserta didik sesuai dengan kaidah pendidikan, kode etik guru, dan peraturan perundang-undangan.

g. Memperoleh rasa aman dan jaminan keselamatan dalam melaksanakan tugas

h. Memilki kebebasan untuk berserikat dalam organisasi profesi

i. Memiliki kesempatan untuk berperan dalam penentuan kebijakan pendidik.

j. Memperoleh kesempatan untuk mengembangkan dan meningkatkan kualifikasi akademik peserta didik

k. Memperoleh pelatihan dan pengembangan profesi dalam bidangnya

Dalam melaksanakan tugas keprofesionalan dalam UU No.14 tahun 2005 tentang guru dan dosen, pada ppasal 20 maka guru berkewajiban sebagai berikut :

a. Merencanakan pembelajaran, melaksanakan proses pembelajaran yang bermutu, serta menilai dan mengevaluasi hasil pmbelajaran

b. Mengembangkan dan meningkatkan kualifikasi akademik dan kompetensi secara berkelanjutan sejalan dengan perkembangan ilmu pengetahuan, teknologi dan seni

c. Bertinjak objektif dan tidak diskriminatif atas dasar pertimbangan jenis kelamin, agama, suku, ras, dan kondisi fisik tertentu, atau latar belakang keluarga dan status sosial ekonomi peserta didik dalam pembelajaran.

d. Menjunjung tinggi peraturan perundang-undangan, hukum dan kode etik guru, serta nilai agama dan etika.

e. Memelihara dan memupuk persatuan dan kesatuan bangsa .( Susanto, 2020 : 39 - 45, 47 - 48 ) 


\section{GURU INDONESIA DAN TANTANGAN PROFESIONALISME}

Profesionalisme guru diperlukan untuk memajukan pendidikan indonesia karena Dengan mengingat berat dan kompleksnya membangun pendidikan, adalah sangat penting untuk melakukan upaya-upaya guna mendorong dan memberdayakan tenaga pendidik untuk semakin profesional. Hal ini tidak lain dimaksudkan untuk menjadikan upaya membangun pendidikan kokoh, serta mampu untuk terus menerus melakukan perbaikan ke arah yang lebih berkualitas. Profesi pendidik merupakan profesi yang sangat penting dalam kehidupan suatu bangsa. Hal ini tidak lain karena posisi pendidikan yang sangat penting dalam konteks kehidupan bangsa. Pendidik merupakan unsur dominan dalam suatu proses pendidikan, sehingga kualitas pendidikan banyak ditentukan oleh kualitas pendidik dalam menjalankan peran dan tugasnya di masyarakat. Oleh karena itu, upaya-upaya untuk terus mengembangkan profesi pendidik (guru) menjadi suatu syarat mutlak bagi kemajuan suatu bangsa, meningkatnya kualitas pendidik akan mendorong pada peningkatan kualitas pendidikan baik proses maupun hasilnya. ( Mustofa, 2007:77 \& 80 )

Kokmpenen Kompetensi yang harus dimiliki guru untuk dapat disebut sebagai guru profesional yakni sebagai berikut:

\section{Kompetensi Profesional Guru}

Kompetensi profesional berasal dari dua kata yaitu kompetensi dan profesional. Kompetensi profesional guru ialah kemampuan dan wewenang guru dalam menjalankan profesi keguruannya, artinya guru yang piawai dalam melaksanakan profesinya dapat disebut sebagai guru yang berkompeten dan profesional

\section{Kompetensi Pedagodik Guru}

Pedagodik adalah teori mendidik yang mempersoalkan apa dan bagaimana mendidik sebaik-baiknya ( Suardi, 1979: 113)

3. Kompetensi Sosial Guru 
Kompentensi Sosial guru merupakan kemampuan guru untuk memahami dirinya sebagai bagian dari masyarakat dan mampu mengembangkan tugas sebagai anggota masyarakat dan warga negara ( Satori, dkk, 2008:2015)

\section{Kompetensi Kepribadian Guru}

Kompetensi kepribadian merupakan salah satu jenis kompenen yang perlu dikuasai guru, selain 3 jenis kompetensi lainnya: Sosial,pedagodik dan Profesional. Dalam penjelasan Peraturan Pemerintah No. 19 Tahun 2005 tentang Standar Nasional Pendidikan disebutkan bahwa kepribadian guru yaitu kemampuan kepribadian yang : (1) mantap: (2)stabil; (3) dewasa; (4) arif dan bijaksana ; (5) berwibawa ; (6) berakhlak mulia;(7) menjadi teladan bagi peserta didik dan masyarakat; (8) megevalusai kinerja sendiri ; dan (9) mengembangkan diri secara berkelanjutan. ( Susanto, $2020: 62-63,67,74,80$ )

\section{SIMPULAN}

Konsep Profesi adalah suatu jens pekerjaan yang menuntut kompetensi khusus melalui proses pendidikan yang lama pada pendidikan tinggi Profesi Guru, Berdasarkan UU RI No.14 tahun 2005 tentang guru dan dosen Pasal 1, guru adalah pendidik profesional dengan tugas utama mendidik, mengajar, membimbing, mengarahkan, melatih, menilai, dan mengevaluasi peserta didik pada pendidikan anak usia dini jalur pendidikan formal, pendidikan dasar, dan pendidikan menengah Profesionalisme guru diperlukan untuk memajukan pendidikan indonesia karena Dengan mengingat berat dan kompleksnya membangun pendidikan, adalah sangat penting untuk melakukan upaya-upaya guna mendorong dan memberdayakan tenaga pendidik untuk semakin profesional. Kokmpenen Kompetensi yang harus dimiliki guru untuk dapat disebut sebagai guru profesional yakni Kompetensi Profesional Guru, Pedagodik Guru, Sosial Guru serta Kompetensi Kepribadian Guru

\section{REFERENSI}


Efendi, I., Prawitasari, M., \& Susanto, H. (2021). Implementasi Penilaian Pembelajaran Pada Kurikulum 2013 Mata Pelajaran Sejarah. Prabayaksa: Journal of History Education, 1(1), 21-25.

Susanto, H. (2020). Profesi Keguruan. Banjarmasin: FKIP Universitas Lambung Mangkurat.

Susanto, H., \& Akmal, H. (2018). Efektivitas Penggunaan Aplikasi Pembelajaran Berbasis Mobile Smartphone Sebagai Media Pengenalan Sejarah Lokal Masa Revolusi Fisik Di Kalimantan Selatan Pada Siswa Sekolah Menengah Atas. HISTORIA: Jurnal Program Studi Pendidikan Sejarah, 6(2), 197-206.

Susanto, H., Irmawati, I., Akmal, H., \& Abbas, E. W. (2021). Media Film Dokumenter Masuknya Islam Ke Nusantara dan Pengaruhnya Terhadap Keterampilan Berpikir Kritis Siswa. HISTORIA: Jurnal Program Studi Pendidikan Sejarah, 9(1).

Syaharuddin, S., \& Susanto, H. (2019). Sejarah Pendidikan Indonesia (Era Pra Kolonialisme Nusantara sampai Reformasi). Banjarmasin: FKIP Universitas Lambung Mangkurat.

Jamil Suprihatiningrum, M. Pd, Si (2012) Guru Profesional, Pedoman Kinerja, Kualifikasi \&Kompetensi Guru (2012), Jakarta

Adiningsih, NU. "Kualitas dan Profesionlisme Guru". (2002). Pikiran Rakyat (Online) Oktober, (http://www.pikiranrakyat.com) 